\title{
Writing Law at the Edge of Empire: Evidence from the Qazis of Bharuch (1799-1864)
}

\author{
E L I Z A B ETH LHOST* \\ E-mail: elizabeth@wisc.edu
}

\begin{abstract}
When judicial department officials at Bombay began to enforce the British East India Company's (EIC) authority over the production and authentication of certain types of legal documents in the late 1830s, qāż̌s (Islamic judges) like Sayyid Ahmad Husain of Bharuch, objected to their loss of authority. In petitions sent to the Governor in Council from the edges of empire, these legal intermediaries objected to the Company's interference with their livelihoods. Although the qazis' complaints did not yield the desired results, by demonstrating the utility of their record-keeping abilities, qazis were able to retain discrete rights. The effects of these negotiations demonstrate the ways in which the intersections of expanding Company policies and local legal activity contributed to the growth of imperial power. Attending to the particularities of local legal practice, captured in the writings of these qazis, this article highlights the material mechanisms by which the EIC co-opted existing documentary cultures to extend state surveillance over local populations and challenges prevailing histories of legal translation and codification by focusing on the social ramifications of changing legal definitions at the moment such relations were first articulated in writing.
\end{abstract}

Keywords: South Asia, Islamic law, British Empire, documentary regimes, local legal practice.

\section{Introduction}

When Sayyid Aḥmad Husain, qāzị ( $q \bar{a} d \bar{l}$, judge) for the city of Bharuch in western Gujarat, lost the right to collect fees for affixing his seal and signature to an array of important legal documents following an order from the judge at the Sadr Court of 'Adālat in Surat in 1839, he promptly dispatched a petition to the Governor in Council at Bombay complaining of the local judge's affront to his status and access to income. ${ }^{1}$ In his complaint, the qazi enumerated several charges against John Romer, the judge at

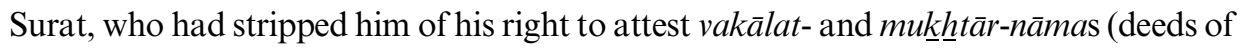


representation) executed "both for the court and private use."2 This task, which had been part of the qazi's domain prior to the British East India Company's interference, helped secure private rights and provide public stability by drawing on the qazi's skills of investigation and authentication. Taking away this right, Sayyid Ahmad Husain argued, would "prove detrimental" to the qazi, who would suffer great losses of income, and to the "Sirkar and Ryot (government and citizenry)," who would also suffer without the qazi's guarantee. Unfortunately, despite these protestations, the qazi's complaint earned him no reward. The judges of the Sadr Court remained firm in their decision to take over these and other documentary protocols formerly belonging to the office of the qazi.

Though the relationship between paper practices and imperial power has received increased attention in recent years, the qazi's role in executing legal documents has yet to receive serious consideration. ${ }^{3}$ The analysis that follows therefore examines the qazi's role as a legal intermediary first in the context of the East India Company's (EIC) changing orientation to paperwork and to the authority of local documentation and second in relation to the diverse populations of merchants, traders, landowners, and agriculturalists in the coastal regions of western India he served. It argues that the qazi's ultimate failure to retain control over multiple forms of legal documentation relevant to Company interests marked a decisive shift in the qazi's social status and legal function that had long-term ramifications for the construction and interpretation of religious law in British India. ${ }^{4}$ Sayyid Ahmad Husain and other members of his family were not the only qazis to engage Company officials in these types of negotiations, but the family's prolonged engagement with the Companyand ultimate decision to heed Company demands - reflect larger transformations in the history of legal writing and document production that opened the door to future incursions into the definition of legal identity and legal activity-definitions that continue to resonate in postcolonial South Asia today. From the family's assistance establishing law and order after the British takeover of the city, to Ahmad Husain's negotiations for a more expansive definition of his office, to his son Nūr-ud-dīn Husain's role in the production of registers legible to the state, the family's professional trajectory stands as an important case study in the history of British expansion and legal-imperial domination in South Asia.

\section{The Calligraphic Company State ${ }^{5}$}

In the context of imperial expansion, contests over the execution and interpretation of legal documents constituted an important arena in which different modes of legal life "jockeyed" with one another for supremacy. ${ }^{6}$ In some locations, such contests resulted in the complete disregard for existing systems of sovereignty and prevailing claims to property in exchange for European modes of laying claim to and establishing ownership. ${ }^{7}$ In the case of western India at this time, such negotiations materialised in acts of terminological appropriation and rough approximation, bringing a diverse array of documentary forms under common rubrics comprehensible to Company officials. 
Legislation flattened entire aspects of indigenous legal life, erasing nuance through translation into European languages and overriding local difference through attempts to understand diffuse legal processes via orthodox interpretations. ${ }^{8}$ Such activities privileged specific understandings of what constituted the "legal" and placed other practices outside the recognised legal order. ${ }^{9}$ Matters pertaining to marriage and other "doctrinal" issues remained the qazi's responsibility while associated processes of legal

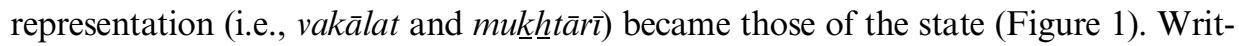
ings produced by intermediaries such as Ahmad Husain trace this transformation, indexing the terminological transformations that marked the pernicious process through which colonial rule constructed categories of religious life and law at a time when jurisdictions, domains, procedures, and modalities were yet unsettled.

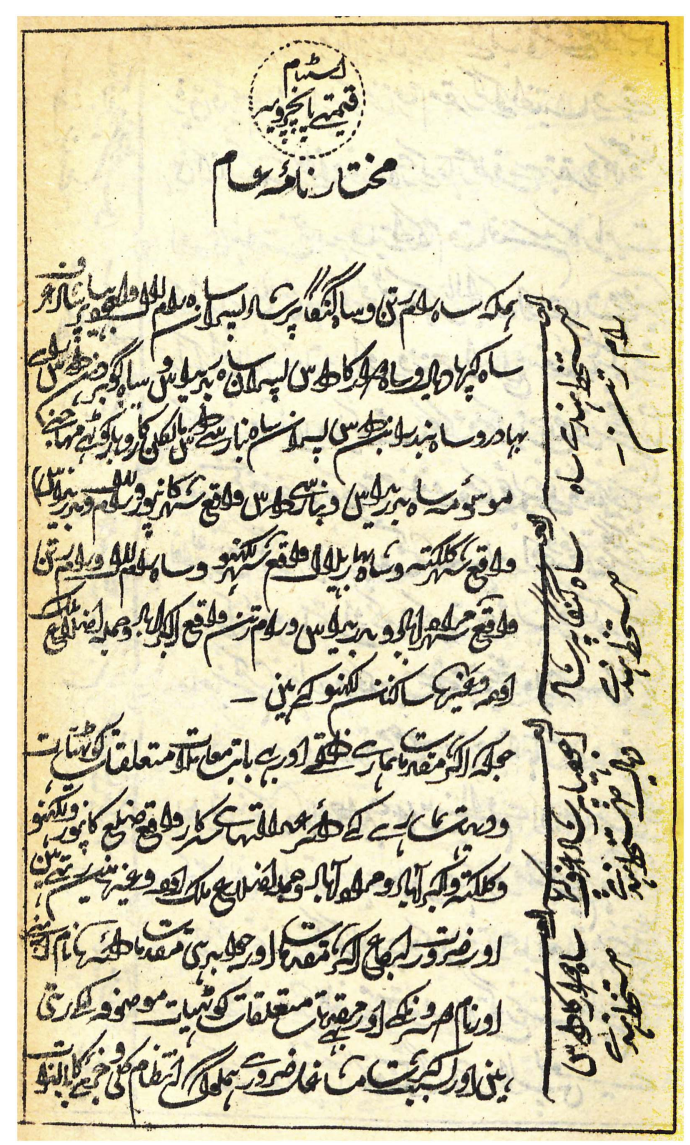

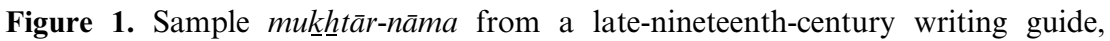
showing the use of five-rupee stamp paper at the top. Courtesy of the British Library. (C) British Library Board (Asia, Pacific and Africa Printed Books and Serials, 14117.b.27(2), Maulvī Sayyid Bāqir 'Alī, Majmū'a-yi Kāghąazāt-i Kārravā'̄o [Lucknow: Gulshan-i Muhammadī Press, 1890], 51). 
Scholarship from across the subcontinent has demonstrated that within the context of British expansion, intermediaries, interpreters, spies, scribes, translators, news-writers, and letter-carriers made vital contributions to the project of imperial knowledge production and domination. ${ }^{10}$ What emerges from these studies is a common argument linking information orders and scribal practices with imperial expansion through the production, translation, interpretation, and possession of written records. Law was also central to this project such that "knowing the country," to use C. A. Bayly's expression, was synonymous with acquiring, analysing, and controlling the production of legal documents. While the historiography on colonial legal change is rife with studies of colonial efforts to translate and codify religious law, interest in the appropriation and transformation of existing documentary forms has received far less attention. ${ }^{11}$ The present study uses documents written and preserved by a family of qazis from Bharuch to explore this aspect of legal history and to trace the effects of legal categorisation on the articulation and documentary construction of socio-familial relations. Such records demonstrate the everyday materiality of law as it intersected with and confronted the ideologies of imperial translation projects.

As legal intermediaries, well versed in the authorial skills necessary to turn the vicissitudes of ordinary life into the language of legal writing, qazis held a position of privilege within this scramble for information. They were channels through which EIC directives could move and sluices capable of curtailing the flow of information. ${ }^{12}$ In their negotiations with the Company state, the qazis of Bharuch not only resisted wholesale appropriations and attempts to import entire categories of legal activity into the domain of the Company's subordinate courts but also contributed to the process of translating local practices into forms more readily recognised by the state. Ahmad Husain and his colleagues brokered information exchanges between Company civil servants anxious to quell rural disorder and local individuals who sought protection in the law to safeguard their everyday transactions. Losing the right to oversee the diversity of documents formerly within their domain, while retaining the right to produce the documents Company officials considered properly "doctrinal" or religious at the end of these negotiations, marked not simply the qazis' loss of status in the face of legal modernisation but more importantly the making of a legal category for the qazis' now-identified "Muslim" clients - one that would have lasting effects on legal access and status in the decades to follow. The transition from a world of legal heterogeneity to one characterised by codified uniformity, however, took time, and the qazis of Bharuch played but one part in this transformation. ${ }^{13}$

\section{A History of Service to the State}

Negotiations between the qazis of Bharuch and Company administrators spanned four generations of Ahmad Husain's family and surfaced during several successive phases of Company policy (see Figure 2 below). The family's documented interactions began in 1803 when, following its takeover of Bharuch, the Company acknowledged the claim to the office of qazi of Zain-ul-'Ābidīn, Ahmad Husain's 


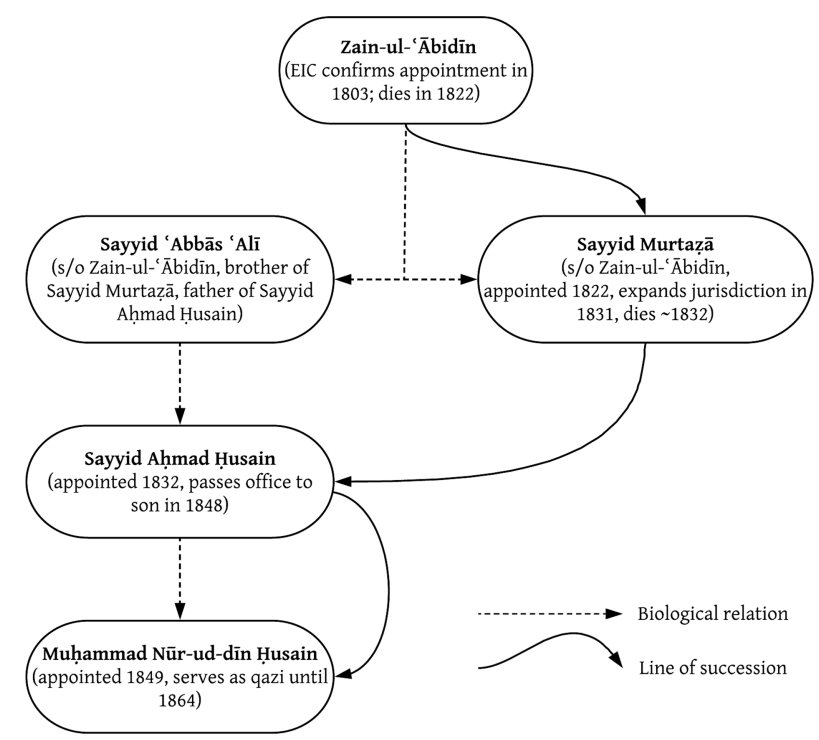

Figure 2. Line of succession for the office of the qazi in Bharuch. (C) Elizabeth Lhost.

grandfather. During Zain-ul-'Ābidīn's lifetime, the Company began the process of converting the qazi's office from one supported by nominal fees and stipendiary entitlements (in the form of land grants, honorary shawls, and other perquisites) to one based in salaried employment. For Zain-ul- ${ }^{-A}$ bidīn, this change meant that upon the recommendation of Judge Charles George Prendergast, who believed the office deserved a higher salary owing to "the difficulty there at present appears to be in procuring Native Law Officers for Company courts possessing the necessary qualification[s]," the qazi began to receive a monthly salary of one hundred rupees, in addition to "the usual presents of a pair of Shawls" (valued at 100-120 rupees) on the

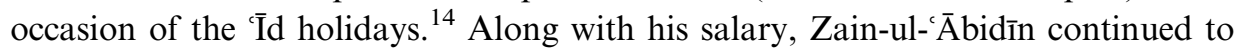
collect fees for authenticating documents and performing marriage ceremonies while also working in the Company's subordinate courts. ${ }^{15}$

When Zain-ul-'Ábidīn passed away in 1822, the position of qazi went to his son, Sayyid Murtazāa. ${ }^{16}$ Once in office, Sayyid Murtazāa successfully extended his jurisdiction from the city to the surrounding district (pargana). After complaining about the harassment he faced "in the discharge of his duties ... in the Purguna," Sayyid Murtazā convinced the judicial commissioner then on circuit to grant him a new sanad (certificate of appointment) as "Kazee of the Town and Purgunnah of Broach," to mark this extension. ${ }^{17}$ When Sayyid Ahmad Husain then became qazi following his uncle's death, he assumed jurisdiction over the expanded territory of the city and the district. As past experiences showed, petitioning the Company was a profitable method for affirming one's status and authority. 
The family further confirmed its hold on the qaziship at Bharuch when Ahmad Husain successfully passed the office to his son, Muhammad Nūr-ud-dīn Husain, in 1849. Although Company policy rejected the idea of hereditary appointments, the judicial department routinely found ways to make exceptions. ${ }^{18}$ Thus, when Ahmad Husain, long-time Company supporter and employee, wrote to announce his impending retirement and to request that the position proceed to his son, the government agreed, following a cursory consideration of the proposed candidate's qualifications. Naturally, Nūr-ud-dīn was rightfully qualified for the office, "well versed in the Persian and Arabic languages," and his family had been "well wishers of the Government long before the rule was established in [the] country." 19 Once again, following a series of petitions, the family secured its position as an ally and important agent of law through expressions of utility and fidelity to the EIC.

Sayyid Ahmad Husain's above-cited complaint against Judge Romer, however, drew upon more than the family's reputation: it explicitly cited the economic losses he faced as a direct result of this most recent interference. As part of his complaint, Ahmad Husain claimed to earn upwards of seven hundred rupees annually for his work signing and sealing documents like vakälat- and mukhtār-nāmas. ${ }^{20}$ Certainly, given their professional status, the family was not destitute, but there is little evidence to support the particularities of his complaint. A government statement compiled in 1864 calculated the total annual income for the qazi of Bharuch at Rs. 786, the majority of which (Rs. 570) came from endowments and the remainder of which (Rs. 216) the qazi received in the form of tributary khil' $a t$ s (robes). ${ }^{21}$ Receipt of this amount annually made the qazi of Bharuch one of the highest-paid functionaries in the Bombay Presidency, earning more than qazis in neighbouring towns, and demonstrating his symbolic-and administrative-importance for British rule.

In the eyes of Company officials, however, the qazi was a religious figure whose domain extended only to matters of a "doctrinal" nature, belonging to religious ritual and what would become the contents of Islamic personal law. ${ }^{22}$ From this perspective, powers of attorney and other deeds of representation did not fall within his ambit and consequently belonged to the documentary purview of the growing Company state. Narrowing the qazi's authority to the categories of religious personal law necessarily limited the application of his expertise to an artificially delimited range of legal transactions. Furthermore, what Company policy did not acknowledge was the extent to which vakālat-nāmas, muk $\underline{h} t \bar{a} r-n \bar{a} m a$ s, and other purportedly "secular" documents were embedded within the material practices of documenting and performing "religious" functions like overseeing marriages and divorces. That is, even in the context of religious practice, these transactions called upon a web of legal documentary forms, many of which Company officials felt belonged to the jurisdiction of their "secular" courts. In this regard, then, evidence from the records of the qazis of Bharuch demonstrate that EIC negotiations not only limited the types of transactions over which the qazi could exercise his authority but also recast those transactions within an Anglophone understanding of marriage and divorce, redefining how such 
transactions were negotiated and executed in documents the qazi had formerly produced with an eye toward other social, economic, and material concerns. ${ }^{23}$

\section{The Life of a Local Qazi}

Company records provide ample evidence about the nature and substance of the qazis' complaints against new policies but provide little information about their dayto-day work. Such considerations require additional sources. Fortunately, relevant sources for the qazis of Bharuch exist in the form of manuscripts, loose documents, and registers previously belonging to the family, including an important manuscript titled A Manual for Qazis and Muftis, which was compiled toward the end of the eighteenth century. ${ }^{24}$ Now held in the Oriental Records section of the National Archives of India, the manuscript comprises fifty-six pages of Persian-language text with interlinear glosses, translations, and brief explanations. The work provides little instruction for a local qazi looking to establish his practice in a particular locale but offers instead an overview of the documents qazis would author and authenticate.

Documents included within the compilation speak to the breadth of the qazis' notarial practices, but the English title affixed to the manuscript is misleading. The socalled manual includes no discussion of the qazi's roles or responsibilities, nor does it describe proper methods for maintaining records, performing public services, or training for the office, as one might expect from a work belonging to the $a d a b a l-q \bar{a} d \bar{\imath}$ (manners and etiquette of qazis) genre. ${ }^{25}$ Instead, the text provides only copies of legal documents, collected almost entirely from popular works of munshāt in circulation at the time. ${ }^{26}$ Close reading shows that entire sections of the text are copied from common works of insh $\bar{a}^{2}$, including chapters six and seven of Harkaran Dās Kanbōh's Insha'-yi Harkaran, which relate to legal agreements (qabālajāt-i shar $\bar{\imath}){ }^{27}$ Nonetheless, the simple act of copying provides insights into the author's own perception of the office. The selection of certain documents demonstrates the compiler's interest in some legal forms over others, while the reference to well-known works of inshä place him within the wider world of Mughal intellectual life and Indo-Persian literary culture more broadly. Furthermore, the fact that only certain legal documents from these works of inshā made their way into the Bharuch Manual underscores the connection between the selected documents and the qazi's daily life. More a commonplace book than a rule-bound manual, the Bharuch Manual stands as a miscellaneous collection of everyday document forms gathered into a single text for ease of regular reference, offering a detailed snapshot of legal documentary culture in late-eighteenth-century Gujarat. ${ }^{28}$

Interlinear notes and marginal glosses further underscore the text's aims and hint at the compiler's need to rely upon such devices to understand and interpret the technicalities of the documents he produced. ${ }^{29}$ For instance, the compiler glosses terms like intif $\bar{a}^{c}$ (profit, benefit) as fá ${ }^{\prime}$ ida (profit, gain), marks nafs (soul, spirit, self) as $\underline{z} \bar{a} t$ (essence, substance, self), and explains the title of a sample $i^{c} t \bar{a} q$ nāma (deed of manumission) using the more common term $\bar{a} z \bar{a} d$ (freedom, emancipation). In sum, 
these explanatory notes point to a preference for Persian expressions over their more legalistic Arabic equivalents and highlights the text's didactic application. ${ }^{30}$ In this way, the Bharuch Manual showcases the qazi's day-to-day activities as notary and illustrates the importance he placed on the accurate transcription and interpretation of legal documents. ${ }^{31}$ Further enquiry into the linguistic register of Persian prevailing at the time could, perhaps, situate the text more accurately within the local Bharuch milieu, but even without extensive lexicographic analysis, the text's interlinear notes clarify the work's purpose as an instrument of instruction and accessible aidemémoire.

Orthographic variation also draws attention to the text's geographic origins and its local relevance. For example, the text's only sample färigh $\underline{h} \underline{k} \underline{h}$ att $t \bar{\imath}$ (a deed of release found in the qazis' registers discussed below) appears in the section of the Manual copied from the Inshä'-yi Harkaran under the heading "pāra-khatțī." "32 The divergent spelling here could reflect a conscious decision to replace the Arabic word färigh $\underline{h}$ (void, vacant) with the Persian pāra (as in, pāra-pāra kardan, to tear to pieces, to nullify), but a more likely explanation lies in the nature of the local Gujarati script. In Gujarati, the aspirated pha and the fricative $f a$ are represented with the same character, rather than with two distinct characters, as in Persian. From the cover pages of the qazis' later registers containing fārigh $\underline{k}$ hattị̂ns, this explanation becomes even more probable. These headings identify the registers' contents with the word phärēg, written in the Gujarati script, rather than with the term färigh $\underline{h}$, written in the Perso-

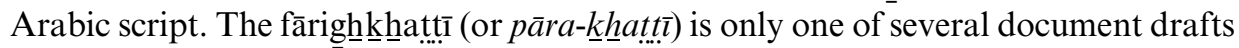
replicated in the Bharuch Manual but the orthographic shift noted here - as well as in the document's conversion from a generic form of debt release to one of divorce noted in the registers analysed below - illustrates one of the ways terminological adjustments marked larger changes in the construction and redefinition of legal categories at this time.

As a collection, the Bharuch Manual reveals the diversity of documentary forms and legal matters that constituted the qazi's professional activities around the turn of the nineteenth century. Altogether, the text contains draft copies of nearly fifty documents, encompassing numerous kinds of agreements and arrangements, from documents for buying and selling houses (bai ${ }^{\complement}$ nama-yi hawì $\bar{l}$ ), gardens (tamassuk- $i$

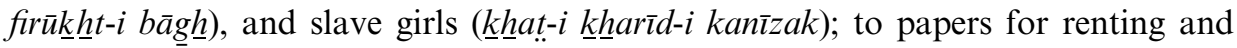

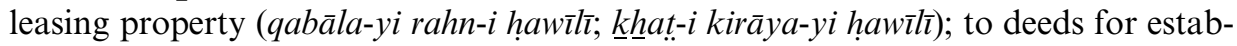
lishing heirs and dividing inheritances (qasm nāma; wirāṣat nāma); to certificates for manumitting slaves ( $i^{\dagger} t \bar{a} q$ nāma; $\bar{a} z \bar{a} d$ nāma-yi gh $\underline{h} u l \bar{a} m$ ) and recording animal casualties (saqț-nāma-yi asp). In addition to commercial documents acknowledging

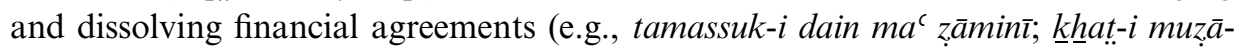
rabat; pāra knhatți wa lā d'awá), the manual also includes deeds of marriage (nikāh nāma) and divorce (talāq nāma). ${ }^{33}$ In short, the contents cover a range of social, economic, and material relations that surpass the narrow definition of "doctrinal" ascribed to the qazi's office in Company discourse and make it clear that the qazi signed and authorised multiple types of transactions in his everyday course of affairs. $^{34}$ 


\section{Local Notarial Practice}

Before the qazis of Bharuch began to maintain registers as servants of the EIC under the directives of Regulation XXVI of 1827, they dealt in individual documents. ${ }^{35}$ The family's extant collection includes a dozen specimen from 1670 to 1816 CE (1080$1231 \mathrm{AH}){ }^{36}$ The majority of these documents are deeds of sale for single-storey houses and small parcels of land, but together, the documents provide useful information about social relations, property ownership, and legal activities in and around the city of Bharuch. They include references to property held under security bonds (tamassuk) certified by the qazi (ba-muhr-i in $\underline{k} \underline{h} \bar{a} d i m-i$ sharc $-i$ shariff); to the acknowledgement of rights of inheritance involved in the sale of different parcels; to the existence of joint ownership, incorporation (musharakat), or the lack thereof in some cases; and to representation before the qazi personally (așālatā̃u) or through an agent (vakālatāñ). Furthermore, although the documents cover a range of years from Aurangzeb's reign (r. 1658-1707) to the early colonial period (e.g., 1231 AH/1816 $\mathrm{CE})$, they exhibit many features in common.

As was customary, the documents bear the seal of the qazi (see Figure 3), or, as in one example, that of the mufti. ${ }^{37}$ Some also include private seals among the attestations, though most witnesses simply signed the deed. Persian is the primary language, but attestations appear in several scripts (Perso-Arabic, Gujarati, Modi, and Devanagari), highlighting the heterographic, if not heteroglossic, context of their production. While witness attestations crowd the main text - often filling the entire righthand margin with a dozen or more statements - the main contracting parties often mark their assent with a simple "sign" ('alāmāt) or decorative object (e.g., a flower), rather than with a signature. The signatures and "signs" also indicate varying levels of literacy among the contracting parties, suggesting that legal documentation was not the exclusive domain of literate merchant communities but that agriculturalists and artisans also participated. ${ }^{38}$

The Bharuch collection reflects a period of transition, from the symbolic elegance of imperial decrees to the pragmatic functionalism of Company practice. ${ }^{39}$ Indeed, the qazis of Bharuch (and their demands to retain the right to author and authenticate all manner of legal documents, including the aforementioned vakālat-and muk $\underline{h} t \bar{a} r-$ nāmas) challenged the Company's documentary hegemony and brought to light the pressing need to declare certain types of documents and deeds the explicit purview of Company scribes and employees. Removing the authority to authenticate "secular" contracts from the legal domain of the qazi's religious or "doctrinal" work was one step toward the redefinition of Islamic law in the nineteenth century. ${ }^{40}$ Eighteenthcentury specimens from the family's collection underscore the transition that took place in the nineteenth century as new documentary regimes modified the qazi's work and altered his notarial position. ${ }^{41}$ The transition from flexible, personal documentation to abstract, tabular notation found in registers not only recast the qazi's day-to-day responsibilities in line with those of Company accountants and administrative minions but also reshaped the very definition of what it meant to contract a 


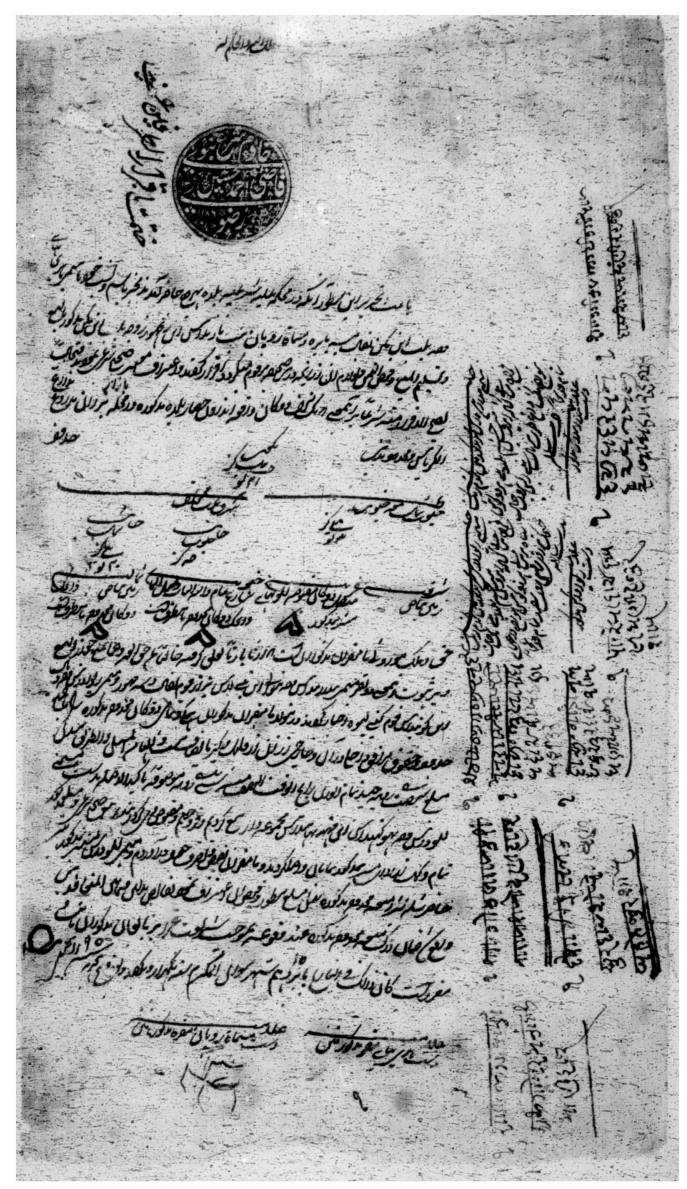

Figure 3. Sale deed from the family archives of the qazis of Bharuch, with the seal of the qazi at the top, and attestations along the right-hand margin. 19 Muharram 1195 AH (15 January 1781 CE). Courtesy of the National Archives of India (Miscellaneous Manuscripts Microfilmed at Bharuch, Acc. No. 851, Sr. No. 45).

marriage - not in terms of what was permissible or possible according to figh (Islamic jurisprudence) but in terms of European notions of marriage, divorce, and other domestic contracts. Registers produced by the qazis of Bharuch illustrate the way novel registration procedures reduced complex, heterogeneous legal agreements to blunt transactional instruments.

\section{From Document to Register}

The introduction of tabular registers in the first decades of the nineteenth century changed the process of performing and documenting transactions with respect to form and content in two important ways. First, the register converted flexible 
narratives into rigid fill-in-the-blank forms. Second, the registers converted speaking subjects into recorded objects. Thus, with the shift from document to register, from private deed to (more) public record, the nature of these transactions also changed. ${ }^{42}$ To demonstrate this point clearly, this section surveys a pair of registers containing fārighkhkhattīis, or deeds of separation and release, as they moved from open-ended transcriptions of private, contractual agreements to tabular records with prescribed contents. ${ }^{43}$ While on the one hand these registers demonstrate prevailing differences between prescriptive formulae and the diversity of local practices, on the other hand they map directly onto the imperial project of separating, categorising, and manipulating categories of legal expression. Evidence from these registers thus points to the ways in which documentary practices shaped the construction of legal identities and the regulation of social practices in the city of Bharuch and throughout British India.

Normative manuals classify the färighk $\underline{\underline{k}} \underline{\underline{h}}$ atțī as a deed acknowledging the repayment of a debt and releasing the debtor. Contemporary law reports and dictionaries confirm this widespread usage and point to the deed's utility in a variety of contexts, from maritime commercial debts to agricultural revenue collection to forms of

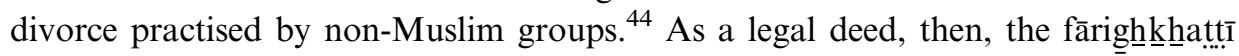
straddled what would become the colonial categories of personal-religious and civil contract law. Entries recorded in the qazis' two registers (see Figures 4 and 5) further evince this transformation from the form's use as an umbrella term covering many types of nullification to one of increasing specificity, referring only to "divorce." This semantic shift points to the larger effects of administrative efforts to fix legal terms generally and in the context of the fārighk $\underline{k}$ hatțī specifically, to move away from more capacious ideas of debt release to more rigid understandings of marital separation. ${ }^{45}$ The registers map these changes directly and materially, but to understand this transformation it is first necessary to consider the scope of the färighkhatți as a legal form.

Fārighkhatțīs recorded in the registers from Bharuch mirror those found in normative texts: "I, who am so-and-so ( falān), son of so-and-so, born of so-and-so, state and legally affirm that I release so-and-so from any obligation to me." ${ }^{46}$ The differ-

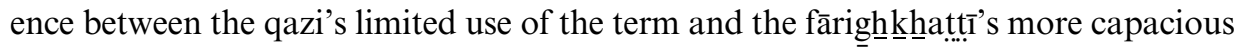
definition is that in Bharuch, the contractual bind between the two parties is one of marital debt and obligation. Rather than mentioning an "account" (hisāb) or "property" $(m \bar{a} l)$, as normative models might imply, the document now refers to "marital relations" ('alāqa-yi zaujīyat) and to the "bond of marriage" (qaid-i nikāh). Though it is tempting to read these documents simply as evidence of the qazi's turn to family affairs, such a reading misses the legal-contractual nature of marriage in Islam and privileges instead the sacral, Christian definition of marriage. Indeed, the documents themselves retain the language of contracts and mutually constituted obligations and expectations reflective of the form's other uses and the qazi's wider sphere of legal practice. That is, in its earlier iterations, the färighkhatțī resisted easy classification and was not constrained to religious or "doctrinal" matters, as Company 


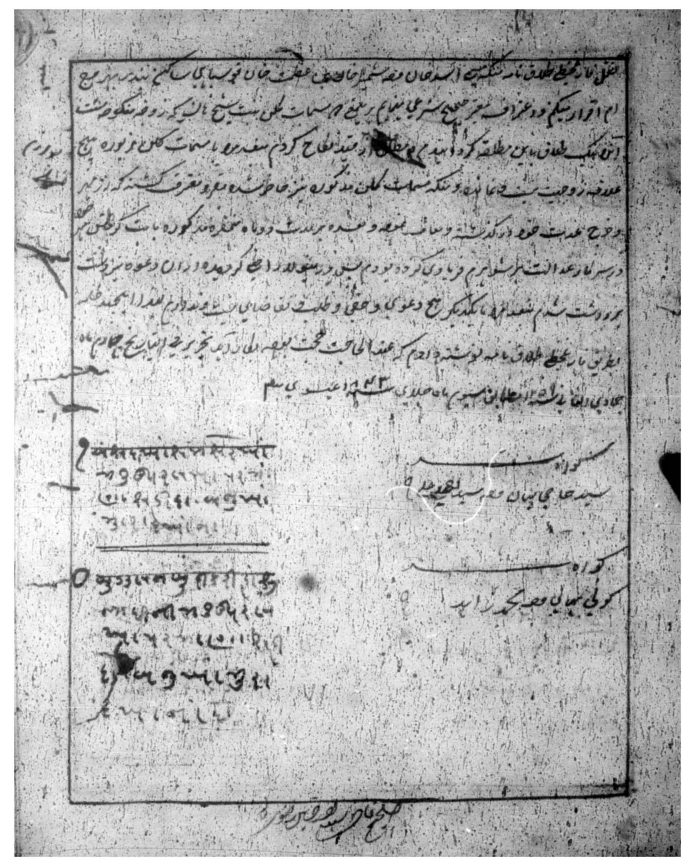

Figure 4. Färighk $\underline{h} a t \underline{t} \bar{l}$ from the collection of the qazis of Bharuch, with witness signatures below, and the qazi's certification at the bottom of the page. 4 Jumādi aș-ṣan̄i 1259 AH (3 July $1843 \mathrm{CE}$ ). Courtesy of the National Archives of India (Miscellaneous Manuscripts Microfilmed at Bharuch, Acc. No. 851, Sr. No. 41, Entry 3).

policy soon began to dictate. ${ }^{47}$ Replicating normative models, then, entries in the register appear as follows:

I, who am named Shaikh Mīr Muhammad, son of Kālū, of the weaver community [qaum], ... residing at Bharuch, state and legally affirm to this effect that I release one Zainab, daughter of Khaisā Bhā'̄ì, who is my lawfully wedded wife [zauj-i mankūḥa-yi man ast] from the confines of marriage after which there will not be, nor will remain, any marital connection between myself and the aforementioned Zainab. ${ }^{48}$

Given that Islamic law considers marriage a form of civil contract - a fact British civil servants struggled to comprehend well into the nineteenth century - the text translated above is not unexpected. ${ }^{49}$ What is important to note, however, is the qazi's instrumentality in establishing and nullifying these marital relationships through the application of this generic legal form. Though most of the fārigh $\underline{\underline{k}} \underline{k} \underline{h}$ atțīs recorded in these registers refer to divorce by mutual consent (for which there is no exchange of money or property) and reflect obligations and indebtedness rooted in the bonds of marriage, the register records other modes of separation as well. The document also requires the presence of - and gives voice to-both parties involved. After the 
husband's opening statement, then, the entries also record the second party's statement, acknowledging the wife's presence and recording her testimony:

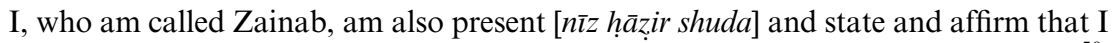
abstain from mahr and the expense of 'iddat owed to me and forgive [these debts]. ${ }^{50}$

After both parties have spoken, the entry concludes with a statement confirming the terms of the release:

After this agreement, there is no claim, admission, request, or demand nor will any remain [between us]. Consequently, I [the qazi] have written [nawishta] and provided these brief remarks [in chand kalima] so that when required, they may serve as proof. Written on the 3rd of Rabī al-awwal 1259 Hijrī, corresponding to 4th April 1843 CE. ${ }^{51}$

The parties then sign the entry-here Mīr Muhammad signs in Perso-Arabic script while Zainab writes her name in Gujarati - and the witnesses affix their signatures (or signs). In this example, the four witness add their names in the Gujarati script, and the separation is complete. ${ }^{52}$

In the context of a highly mobile, mercantile population, access to documentation for legal separation can be as important as documentation for legal obligation. Thus, the deed of divorce by mutual consent should not be misread as an attempt to limit the woman's access to economic or social capital. Rather, the deed's easy execution and implicit acknowledgement of mutual debt and obligation reflect the legal subject-hood of both parties. Furthermore, the registers containing such färighkhattị̂s acknowledge the qazi's central role in providing access to legal documentation for the purposes of creating, and in this case, terminating relationships. Despite the qazi's centrality for documenting and authenticating the dissolution of such relationships, the pressures of bureaucratic record-keeping, already visible across these two registers of färighkhhattị̄s (Sr. Nos. 41 and 42), compounded his transformation from non-religious notary to Islamic officiant.

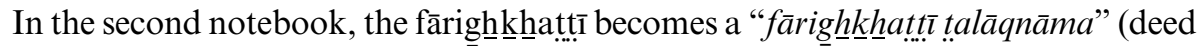
of separation and divorce), bringing the multiple possibilities of separation (fârig $\underline{h}$ ) under the singular heading of talä (divorce) and making the heterogeneous possibility of the fārighk $\underline{k}$ hattị compliant with EIC understandings of religious personal law under the heading "divorce." ${ }^{53}$ With this change, the tabular layout also modified the composition of the legal agreements it recorded. Narrative statements allowed for individual variation and specification, but the tabular formats preferred by Company officials made the completion of an entry the only evidence of its legality. That is, where narrative statements embedded legal power within the complex of written statements, witness testimonies, and the qazi's authority, register entries by contrast relied on the page's filled-in spaces alone (see Figure 5). As such, the transition from narrative statement to tabular layout not only excised from his domain the flexible elements that allowed the qazi of Bharuch to interact with Gujarat's diverse population but also turned the written contract imbued with legal authority into a register entry now dependent upon British interpretations of doctrinal practice. On paper, the qazi had become a religious figure solely assigned to handle the "doctrinal" affairs of the Muslim community. 


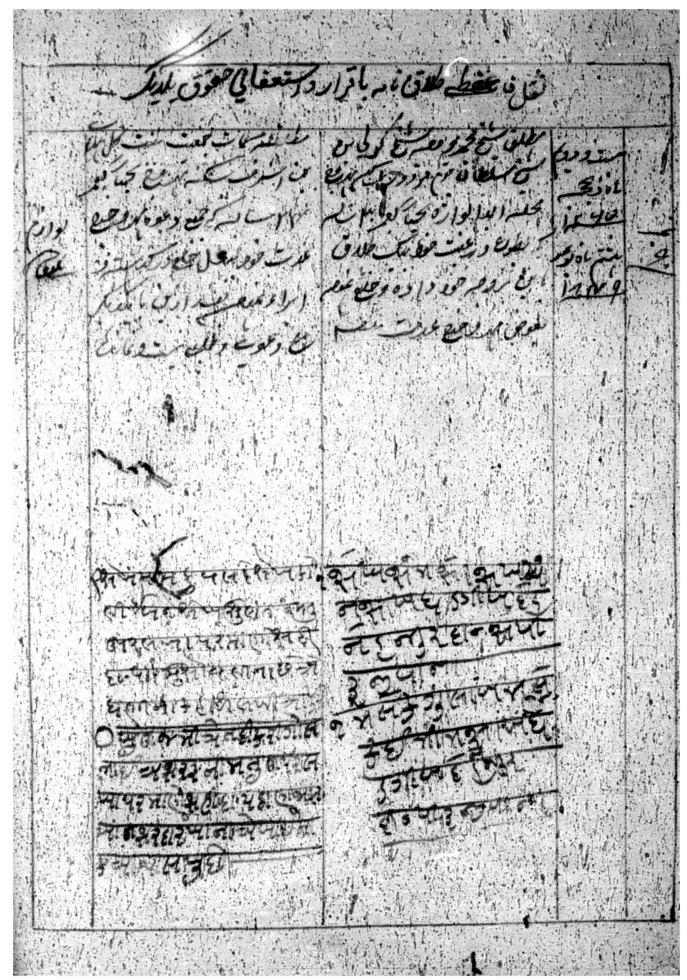

Figure 5. Tabular färighk $\underline{h}$ atți-talāq-nāma from the collection of the qazis of Bharuch. 22 Zī al-hijja 1265 ( 7 November 1849). Courtesy of the National Archives of India (Miscellaneous Manuscripts Microfilmed at Bharuch, Acc. No. 851, Sr. No. 42, Entry 9).

Despite their efforts to negotiate with the Company, the qazis of Bharuch were unable to retain control over the range of legal deeds and documents they previously authorised, but at the same time, by asserting their rights to maintain limited records, the qazis' transformation indexed the establishment of new legal categories-public and private, commercial and personal, secular and doctrinal - with categorically British valences. In so doing, the transformation of the färighkhhatți from a deed of nullification and separation into a deed of divorce reflected a new interpretation for the qazi's work in Bharuch and produced a quintessentially communal interpretation of his records. Rather than marking a steady progression from status to contract, the reconfiguration of the qazi's work in nineteenth-century Bharuch instead marked a turn from written contract to religious-legal status. ${ }^{54}$

\section{Conclusion}

Considering the effects of social translation that accompanied the process of scribal transformation elsewhere, it is no surprise that qazis familiar with earlier modes of 
notarial practice confronted imperial policy on the grounds of personal and public loss. Though it was perhaps not possible to see at the time, changes in documentary authorship prefigured even greater changes in the formulation of legal categories. ${ }^{55}$ British conceptions of legal authority could not account for the plurality of experiences, exchanges, and evidence made possible under the generic heading of the fār-

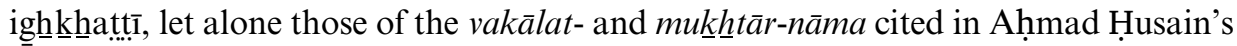
initial complaint. Drawing an ever-tighter circle around the modes and forms of writing over which qazis could exercise authority was thus part of a much larger process of legal transformation. Along with document forms like vakālat- and mukhhāar-nāmas cited in Aḥmad Husain's original petition, Company officials rejected the qazi's utilisation of the full range of contractual arrangements and nullifications nestled within more expansive definitions of the färighkhkhatțī. Instead, such forms had to be recast under the rubric of "doctrinal," personal, and religious lawdevoid of the heterogeneity and flexibility observed in their earlier iterations. In the context of Company expansion, such narrative statements were dangerously openended. The Company craved documentary specificity, and the qazis of Bharuch followed suit by making their records rigid, eschewing narrative statements in exchange for fill-in-the-blank renderings of acceptable legal status.

Record-keeping at this time did more than simply render legal practices from the edges of empire legible to the imperial bureaucracy; it also transformed the contents of those practices. Once the information became abstracted from its narration, it could no longer account for individual variation without transgressing the written (tabular) arrangement. Predetermined writing practices went beyond the mere fact of recording transactions: they determined the very definition of the exchange. As one of the evidentiary platforms on which the Company manifested its larger programme of legal transformation and appropriation, the qazi's register indexes the extension of imperial policy at the first moment of legal articulation - that is, the moment in which private agreements become publicly cognisable in legal documents. While histories of colonial legal change tend to elide this moment in an effort to highlight the textual translation practices of British officials, qazi registers from Bharuch, in fact, reveal the importance of this moment and draw attention to the influence of legal definition embedded within the initial act of transcription.

Through persistent negotiations with East India Company officials in Bombay, the qazis of Bharuch were able to carve a place for their work in the administration of law at the local level, but such participation was not immune to the policies of colonial categorisation and compartmentalisation. In its categorisation of the qazi as a "religious" official, responsible only for matters of religious "doctrine," Company policy missed the diversity and complexity of the legal agreements individuals like Sayyid Ahmad Husain supervised through their everyday notarial activities as qazi. In this way, Company policy not only divested the qazis of Bharuch of their ability to author and authenticate deeds like vakālat- and mukhtär-nāmas but also removed those (and other documentary) forms from the matrix of deeds and agreements that constituted 
the legal articulation of marital and other social, familial, or commercial relations. The transformation of the färighkhatți in the first decades of the nineteenth century suggests that even where social relations were catalogued and articulated through contractual agreements, Company policy worked to unsettle such agreements from indigenous modes of documentation, reserving certain written forms for "secular" proceedings and relegating others to "religious" fora. Evidence from the qazis of Bharuch thus illustrates how the implementation of categorical assumptions about the application of religious law at the local level reconfigured social relationships before litigants even entered colonial courtrooms.

In the debates surrounding the extent to which the qazis of Bharuch could engage in the authentication and registration of specific legal documents, ideas about the categorisation of legal transactions are already evident. These ideas kept marriage and divorce within the qazi's religio-legal domain while placing concepts of representation and advocacy (vakālat, muk $\underline{h} t \bar{a} r \bar{r}$ ) under the authority of the Company's courts. But drawing the lines separating religious and secular transactions required a redefinition of those terms. If legal progress entails a transition from ascribed status to written contract, then the qazi's records challenge the notion that European law brought the gift of legal documentation to South Asia. Not only do the registers point to the presence of multiple forms of legal agreement (commercial, social, marital)

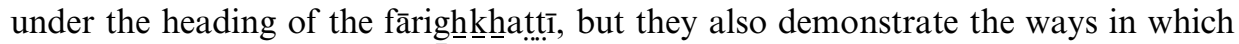
EIC interference actively worked to turn contractual forms into communal categories.

\section{Bibliography}

\section{Archival Sources}

Acquired Manuscripts, National Archives of India (NAI)

Manuscripts Microfilmed at Bharuch (NAI)

Fārighk khhattị Nāmas, Sr. Nos. 41-42

Miscellaneous Documents (1670-1816 CE), Sr. No. 45

India Office Records (IOR), British Library (BL)

India Office Islamic Manuscripts (IO Islamic), BL

Oriental Manuscripts (OMS), BL

Judicial Department Proceedings (JDP), Maharashtra State Archives (MSA)

\section{Published Sources}

Alam, Muzaffar. The Crisis of Empire in Mughal North India: Awadh and the Punjab, 1707-48, 2nd ed. Delhi: Oxford University Press, 2013.

Alam, Muzaffar and Sanjay Subrahmanyam. "The Making of a Munshi." Comparative Studies of South Asia, Africa and the Middle East 24:2 (2004): 61-72. https://doi.org/10.1215/ 1089201X-24-2-61.

Ali, M. Athar. "The Use of Sources in Mughal Historiography." Journal of the Royal Asiatic Society 5:3 (1995): 361-73. https://doi.org/10.1017/S1356186300006623.

Anghie, Antony. Imperialism, Sovereignty and the Making of International Law. New York: Cambridge University Press, 2005. 
Anderson, Michael R. "Islamic Law and the Colonial Encounter in British India." In Institutions and Ideologies: A SOAS South Asia Reader, edited by David Arnold and Peter Robb, 165-85. London: Curzon Press Ltd., 1993.

Anderson, Olive. "The Incidence of Civil Marriage in Victorian England and Wales." Past and Present 69 (November 1965): 50-87. https://doi.org/10.1093/past/69.1.50.

Balfour, Edward. The Cyclopadia of India and of Eastern and Southern Asia: Commercial, Industrial and Scientific Products of the Mineral, Vegetable, and Animal Kingdoms, Useful Arts and Manufactures. 5 vols. London: B. Quaritch, 1885.

Bayly, C. A. The Birth of the Modern World, 1780-1914: Global Connections and Comparisons. Malden: Blackwell, 2004.

- "Colonial Rule and the 'Information Order' in South Asia." In The Transmission of Knowledge in South Asia: Essays on Education, Religion, History, and Politics, edited by Nigel Crook, 280-315. Delhi: Oxford University Press, 1996.

- Empire and Information: Intelligence Gathering and Social Communication in India, 1780-1870. New York: Cambridge University Press, 1999.

_ . "Knowing the Country: Empire and Information in India." Modern Asian Studies 27:1 (1993): 3-43. https://doi.org/10.1017/S0026749X00016061.

—. "Orientalists, Informants, and Critics in Benares, 1790-1860." In Perspectives of Mutual Encounters in South Asian History, 1760-1860, edited by Jamal Malik, 97-127. Leiden: Brill, 2000.

Benton, Lauren. Law and Colonial Cultures: Legal Regimes in World History, 1400-1900. New York: Cambridge University Press, 2002.

—. A Search for Sovereignty: Law and Geography in European Empires, 1400-1900. Cambridge: Cambridge University Press, 2010.

Beverley, Eric Lewis. "Property, Authority and Personal Law: Waqf in Colonial South Asia." South Asia Research 31:2 (1 July 2011): 155-82. https://doi.org/10.1177/026272801103100204.

Borradaile, Harry. Reports of Civil Causes Adjudged by the Court of Sudur Udalut, for the Presidency of Bombay, between the Years A.D. 1800 and A.D. 1824. Bombay: Courier Press, 1825.

Burns, Kathryn. Into the Archive: Writing and Power in Colonial Peru. Durham: Duke University Press, 2010.

—. "Notaries, Truth, and Consequences." AHR 110:2 (2005): 350-79. https://doi.org/ 55510.1086/ahr/110.2.350.

Carroll, Lucy. "Talaq-i-Tafwid and Stipulations in a Muslim Marriage Contract: Important Means of Protecting the Position of the South Asian Muslim Wife." Modern Asian Studies 16:2 (1982): 277-309. https://doi.org/10.1017/S0026749X00007460.

Chatterjee, Nandini. "English Law, Brahmo Marriage, and the Problem of Religious Difference: Civil Marriage Laws in Britain and India." Comparative Studies in Society and History 52:3 (July 2010): 524-52. https://doi/org/10.1017/S0010417510000290.

. "Mahzar-Namas in the Mughal and British Empires: The Uses of an Indo-Islamic Legal Form." Comparative Studies in Society and History 58:2 (April 2016): 379-406. https:// doi.org/10.1017/S0010417516000116.

Cohn, Bernard S. Colonialism and Its Forms of Knowledge: The British in India. Princeton: Princeton University Press, 1996.

_ . "The Command of Language and the Language of Command." In Subaltern Studies IV:

Writings on South Asian History and Society, edited by Ranajit Guha, 276-329. Delhi: Oxford University Press, 1985.

—. "From Indian Status to British Contract." The Journal of Economic History 21:4 (Dec. 1961): 613-28. https://doi.org/10.1017/S002205070010909X.

- "Some Notes on Law and Change in North India." Economic Development and Cultural Change 8:1 (October 1959): 79-93. 
Doniger, Wendy. "Rationalizing the Irrational Other: 'Orientalism' and the Laws of Manu." New Literary History 23:1 (1992): 25-43. https://doi.org/10.2307/469156.

East India Company. Rules, Orders, and Directions Appointed and Established by the Governour and Committees of the East-India Company, for the Well Regulating and Managing Their Affairs in the Parts of India General Rules for the President, Agents or Chiefs, and Their Respective Council. [London: s.n., 1680].

Eliot, Sir H[enry] M[iers] and John Beames. Memoirs on the History, Folk-lore, and Distribution of the Races of the North Western Provinces of India: Being an Amplified Edition of the Original Supplemental Glossary of Indian Terms, vol. 2. London: Trübner \& Co., 1869.

Enthoven, R. E. The Tribes and Castes of Bombay, vol. 1. Delhi: Cosmo Publications, 1975.

Fisher, M. H. "The Office of Akhbār Nawīs: The Transition from Mughal to British Forms." Modern Asian Studies 27:1 (1993): 45-82. https://doi.org/10.1017/S0026749X00016073.

Forbes, Duncan. A Dictionary, Hindustani \& English: Accompanied by a Reversed Dictionary, English and Hindustani. London: W. H. Allen \& Co., 1866.

Forrest, George, ed. Selections from the State Papers of the Governors-General of India, vol. 2, Warren Hastings. Oxford: B. H. Blackwell, 1910.

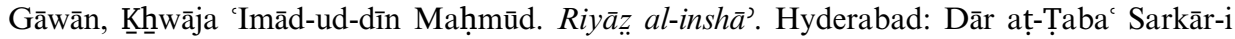
'Ālì, 1948.

Gerber, Haim. State, Society, and Law in Islam: Ottoman Law in Comparative Perspective. Albany: State University of New York Press, 1994.

Gilchrist, John Borthwick. Hindoostanee Philology Comprising a Dictionary, English and Hindoostanee; with a Grammatical Introduction. London: Kingsbury, Parbury, and Allen, 1825.

Grewal, J. S. In the By-Lanes of History: Some Persian Documents from a Punjab Town. Simla: Indian Institute of Advanced Study, 1975.

—. "The Qāzi in the Pargana." In Studies in Local and Regional History, edited by J. S. Grewal, 1-17. Amritsar: Guru Nanak University, 1974.

Guha, Ranajit. A Rule of Property for Bengal: An Essay on the Idea of Permanent Settlement. Durham: Duke University Press, 1996.

Hakīm Yusufī. Bada'̄ al-Inshä’. Delhi: Hindū Press, 1871[?].

Hallaq, Wael B. "Model Shurūt Works and the Dialectic of Doctrine and Practice." Islamic Law and Society 2:2 (1995): 109-34.

_. "The 'Qādī̄s Dīwān (sijill)' before the Ottomans." Bulletin of the School of Oriental and African Studies 61:3 (1998): 415-36. https://doi.org/10.1017/S0041977X00019273.

Hardwick, Julie. The Practice of Patriarchy: Gender and the Politics of Household Authority in Early Modern France. University Park: Pennsylvania State University Press, 1998.

Harikana, Multānī. Inshā-Yi Harkaran = The Forms of Herkern Corrected from a Variety of Manuscripts, Supplied with the Distinguishing Marks of Construction, and Translated into English: With an Index of Arabic Words Explained, and Arranged under Their Proper Roots. By Francis Balfour, M.D. [Calcutta]: Printed at Calcutta [by Charles Wilkins], 1781.

Hasan, Farhat. State and Locality in Mughal India: Power Relations in Western India, c. 15721730. New York: Cambridge University Press, 2004.

Hevia, James. The Imperial Security State: British Colonial Knowledge and Empire-Building in Asia. Cambridge: Cambridge University Press, 2012.

Hull, Matthew S. Government of Paper: The Materiality of Bureaucracy in Urban Pakistan. Berkeley: University of California Press, 2012.

Khassaf, Ahmad ibn 'Umar. Adab Al-Qadi: Islamic Legal and Judicial System. New Delhi: Adam Publishers and Distributors, 2004.

Kinra, Rajeev. "Master and Munshī: A Brahman Secretary's Guide to Mughal Governance." Indian Economic \& Social History Review 47:4 (2010): 527-61. https://doi.org/10.1177/ 001946461004700405 
Writing Self, Writing Empire: Chandar Bhan Brahman and the Cultural World of the Indo-

Persian State Secretary. Berkeley: University of California Press, 2015.

Kozlowski, Gregory C. Muslim Endowments and Society in British India. New York: Cambridge University Press, 1985.

Kugle, Scot Alan. "Framed, Blamed and Renamed: The Recasting of Islamic Jurisprudence in Colonial South Asia." Modern Asian Studies 35:2 (May 1, 2001): 257-313. https://doi.org/ 10.1017/S0026749X01002013.

Likhovski, Assaf. Law and Identity in Mandate Palestine. Studies in Legal History. Chapel Hill: University of North Carolina Press, 2006.

Maine, Henry Sumner. Ancient Law. London: Dent, 1977 [1861].

Malikzādah. Nigārnāma-yi Munshī. Lucknow: Nawal Kishore Press, 1882.

Master, Streynsham. The Diaries of Streynsham Master, 1675-1680, and Other Contemporary Papers Relating Thereto. 2 vols. Edited by Richard Carnac Temple. Indian Records Series. London: J. Murray, 1911.

Masud, Muhammad Khalid. “Adab al-muftī.” Encyclopaedia of Islam Three. Brill Online, 2016.

—. "Adab al-qāẹī.” Encyclopaedia of Islam Three. Brill Online, 2016.

Masud, Muhammad Khalid, Rudolph Peters and David Stephan Powers. Dispensing Justice in Islam: Qadis and Their Judgements. Leiden: Brill, 2006.

Maulvī Sayyid Bāqir 'Alī. Majmū'a-yi Kāghhazātt-i Kārravā'ț. Lucknow: Gulshan-i Muhạmmadī Press, 1890.

Merwick, Donna. Death of a Notary: Conquest and Change in Colonial New York. Ithaca: Cornell University Press, 2002.

Messick, Brinkley. "Evidence: From Memory to Archive." Islamic Law and Society 9:2 (1 January 2002): 231-70.

- "Textual Properties: Writing and Wealth in a Sharia Case." Anthropological Quarterly 68:3 (1995): 157-70. https://doi.org/10.2307/3318072.

Messick, Brinkley Morris. The Calligraphic State: Textual Domination and History in a Muslim Society. Berkeley: University of California Press, 1996.

Mohiuddin, Momin. The Chancellery and Persian Epistolography under the Mughals, from Bábur to Sháh Jahán, 1526-1658: A Study on Inshá', Dár Al-Inshá', and Munshīs Based on Original Documents. Calcutta: Iran Society, 1971.

Nadri, Ghulam A. Eighteenth-Century Gujarat: The Dynamics of Its Political Economy, 17501800. Leiden: Brill, 2009.

Naknhjavān̄̄, Muḥammad ibn Hindūshāh. Dastur al-kātib fì ta'īn al-marātib. Moscow: Idārah-i Intishārāt-i Dānish, 1971.

Niṣār, 'Alī ibn A'ẓam 'Alī. Inshā-yi Dilkushā. Lucknow: Anwār-i Muḥammad Press, 1882.

Nurul Hasan, S. "Nigar Nama-i-Munshi: A Valuable Collection of Documents of Aurangzeb's Reign." In Religion, State, and Society in Medieval India: Collected Works of S. Nurul Hasan, edited by Satish Chandra, 296-303. New Delhi: Oxford University Press, 2005.

Nussdorfer, Laurie. Brokers of Public Trust: Notaries in Early Modern Rome. Baltimore: Johns Hopkins University Press, 2009.

Ogborn, Miles. Indian Ink: Script and Print in the Making of the English East India Company. Chicago: University of Chicago Press, 2007.

Peirce, Leslie. Morality Tales: Law and Gender in the Ottoman Court of Aintab. Berkeley: University of California Press, 2003.

Qasemi, S. H. "Harkarn Dās Kanbōh.” Encyclopæedia Iranica (online edition), December 15, 2003. http://www.iranicaonline.org/articles/harkarn-das-kanboh.

Raman, Bhavani. Document Raj: Writing and Scribes in Early Colonial South India. South Asia across the Disciplines. Chicago: University of Chicago Press, 2012. 
. "The Duplicity of Paper: Counterfeit, Discretion, and Bureaucratic Authority in Early Colonial Madras." Comparative Studies in Society and History 54:2 (2012): 229-50. https:// doi.org/10.1017/S0010417512000023.

Richards, John F. ed. and trans. Document Forms for Official Orders of Appointment in the Mughal Empire: Translation, Notes and Text. Cambridge: Trustees of the E. J. W. Gibb Memorial, 1986.

Saumarez Smith, Richard. Rule by Records: Land Registration and Village Custom in Early British Panjab. Delhi: Oxford University Press, 1996.

Shakeb, M. Z. A. A Descriptive Catalogue of the Batala Collection of Mughal Documents, 1527-1757 AD. London: British Library, 1990.

Sharafi, Mitra. "A New History of Colonial Lawyering: Likhovski and Legal Identities in the British Empire." Law \& Social Inquiry 32:4 (2007): 1059-94. https://doi.org/10.1111/j.17474469.2007.00087.x.

Singh, M. P. (Mahendra Pal). Town, Market, Mint, and Port in the Mughal Empire, 1556-1707: An Administrative-Cum-Economic Study. New Delhi: Adam Publishers and Distributors, 1985.

Singha, Radhika. A Despotism of Law: Crime and Justice in Early Colonial India. Delhi: Oxford University Press, 1998.

Stephens, Julia Anne. "Governing Islam: Law and Religion in Colonial India." PhD diss., Harvard University, 2013.

Sturman, Rachel. The Government of Social Life in Colonial India: Liberalism, Religious Law, and Women's Rights. New York: Cambridge University Press, 2012.

Zilli, Ishtiyaq Ahmad, trans. and ed. The Mughal State and Culture, 1556-1598: Selected Letters and Documents from Munshaat-i-Namakin. New Delhi: Manohar, 2007.

\section{Notes}

* Elizabeth Lhost is a historian of law and religion in South Asia. Her current book project traces the transformation of Islamic legal practice in nineteenthcentury British India using paperwork, bureaucracy, and writing technologies to understand local legal practice during this period. She earned her $\mathrm{PhD}$ in History and South Asian Languages and Civilizations from the University of Chicago and is currently a Mellon Postdoctoral Fellow with the Center for the Humanities and associate lecturer in the undergraduate Legal Studies Program at the University of Wisconsin-Madison. The author would like to thank Nick Abbott, Muzaffar Alam, Dipesh Chakrabarty, Iza Hussin, Rajeev Kinra, and Emily Lynn Osborn for providing valuable feedback on earlier versions of this paper. The author would also like to thank the organisers, Sanne Ravensbergen and Mahmood Kooria, for inviting this contribution and to acknowledge the input and guidance received from the editorial staff at Itinerario and two anonymous reviewers who provided key insights during the revision process. Research for this article was supported by the Fulbright Commission, the Social Science Research Council, the American Institute of Pakistan Studies, the Andrew W. Mellon Foundation, and the American Council of Learned Societies.

Elizabeth Lhost, iD https://orcid.org/00000001-6101-0489.

1 MSA, JDP, Vol. 20 of 1839.

2 Ibid. Vakālat- and mukhtāar-nāmas are deeds of representation or powers of attorney. (Mohiuddin, The Chancellery and Persian Epistolography, 127). On the formalisation of these roles in Banaras, see Cohn, "From Indian Status to British Contract," 626-7.

3 See, e.g., Raman, Document Raj; and Ogborn, Indian Ink. 
4 On legal intermediaries, see Likhovski, Law and Identity in Mandate Palestine; and Sharafi, "A New History of Colonial Lawyering" among others. On the qazi's office, see Gerber, State, Society, and Law in Islam (especially chapter 2); Masud, Peters, and Powers, Dispensing Justice in Islam; and Peirce, Morality Tales.

5 I borrow this expression from Messick.

6 See Benton, Law and Colonial Cultures, 1-30; and Benton, A Search for Sovereignty.

7 The literature on this subject is vast. Relevant examples for South Asia include, Anghie, Imperialism, Sovereignty, and the Making of International Law; Bayly, The Birth of the Modern World, 299-300; Benton, A Search for Sovereignty; and Guha, A Rule of Property for Bengal.

8 Translation as appropriation dominates postcolonial discourse but disentangling these translations requires further enquiry. (See Cohn, "The Command of Language" and "Some notes on Law and Change," along with Anderson, "Islamic Law and the Colonial Encounter"; and Beverley, "Property, Authority, and Personal Law.")

9 Anderson, "Islamic Law and the Colonial Encounter."

10 Bayly, Empire and Information; Bayly, "Colonial Rule and the "Information Order"'; Bayly, "Knowing the Country"; Bayly, "Orientalists, Informants, and Critics"; Fisher, "The Office of Akhbār Nawīs"; Hevia, The Imperial Security State; Ogborn, Indian Ink; and Raman, Document Raj.

11 See Anderson, "Islamic Law and the Colonial Encounter"; Beverley, "Property, Authority, and Personal Law"; Cohn, Colonialism and Its Forms of Knowledge; and Kugle, "Framed, Blamed, and Renamed." For Hindu law, see, Doniger, "Rationalizing the Irrational Other."

12 This reading draws upon recent histories of notarial practice, including Burns,
"Notaries, Truth, and Consequences"; Burns, Into the Archive; Hardwick, The Practice of Patriarchy; Merwick, Death of a Notary; and Nussdorfer, Brokers of Public Trust.

13 For a description of this heterogeneity, see Hasan, State and Locality, 71-6, 91-100; and Singha, A Despotism of Law (especially chapter 1 ).

14 MSA, JDP, Vol. 21 of 1842.

15 Ibid.

16 MSA, JDP, Vol. 6 of 1864.

17 MSA, JDP, Vol. 3 of 1831.

18 On hereditary offices, see Alam, Crisis of Empire, 112-120. On Company efforts to disentangle claims, see Sturman, The Government of Social Life.

19 MSA, JDP, Vol. 21 of 1848.

20 MSA, JDP, Vol. 20 of 1839.

21 MSA, JDP, Vol. 6 of 1864.

22 On the construction of Anglo-Muslim law, see Anderson, "Islamic Law and the Colonial Encounter"; and Kugle, "Framed, Blamed, Renamed." For a reappraisal of the chronology of this process, see Stephens, "Governing Islam."

23 Most scholarship on Islamic law in colonial contexts has focused on aspects of codification and translation in relation to courtroom litigation and the construction of sovereign authority. This article considers the negotiation of legal terms and documentary forms at the level of local practice.

24 NAI, Acquired Manuscript No. 2200.

25 Masud, "Adab al-qā $\widehat{\imath}$ ”; Masud, "Adab al-muftī"; and Khassaf, Adab Al-Qadi.

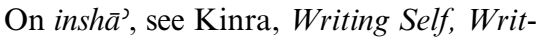
ing Empire; Kinra, "Master and Munshī"; and Alam and Subrahmanyam, "The Making of a Munshi." Some works of inshā', like Malikzādah's Nigār-namayi Munshī, do discuss training and office etiquette in addition to providing epistolary formulae. See Nurul Hasan, "Nigar Nama-i Munshi," 296-7.

26 NAI, Acquired Manuscript No. 2200. The Urdu title, Qāzīōñ aur muftīōn kē liye tahrīirāt kē liyē fārsī musauwadat (Persian Drafts of documents for Qazis 
and Muftis), is more faithful to the contents.

27 NAI, Acquired Manuscript No. 2200, 31-40; Harikaṇa, Inshā-yi Harkaran, 162-76; and BL, OMS Add. 26140, 46a-54a. (On Harkaran, see Kinra, Writing Self, Writing Empire, 28-9; Alam and Subrahmanyam, "The Making of a Munshi," 61; Qasemi, "Harkarn Dās Kanbōh"; and Balfour's preface to Harikaṇa, Inshā-yi Harkaran, 1-7.)

28 Other works include Malikzādah's Nigārnāma-yi Munshī, Maḥmūd Gāwān's Riyāz al-inshā', Maulānā Ḥakīm Yusufi's Bada $i$ al-Insh $\bar{a}^{c}$, and Nișar 'Alī ibn A'ẓam 'Ali's Inshā-yi Dilkushā, and Naknhjavānī's Das$t \bar{u} r$ al-kātib. For translations from and discussions of these texts as historical sources, see Athar Ali, "Use of Sources in Mughal Historiography," 364-7; Nurul Hasan, "Nigar Nama-i Munshi"; Richards, Document Forms; and Zilli, ed., The Mughal State and Culture. (I thank Rajeev Kinra for these references.)

29 The compiler is unknown. The colophon gives the date 4 Ramzān 1213 AH / 9 February 1799 CE but the cover identifies Nūr-ud-dīn Husain as the text's "owner" or "mālik." (NAI, Acquired Manuscript No. 2200.)

30 Ibid., 24.

31 These processes were not mutually exclusive but connected in what Hallaq calls the "dialectic of doctrine and practice." Hallaq, "Model Shurūt Works" and "The 'Qāộis's Dīwān'."

32 NAI, Acquired Manuscript No. 2200, 37. (It is possible to read the Persian $f \bar{a}$ as $p \bar{a}$ in a nāqis [defective] manuscript, but a more likely explanation lies in the transposition from Gujarati.)

33 Ibid.

34 MSA, JDP, Vol. 20 of 1839.

35 For the Regulation XXVI of 1827 , see, $\mathrm{BL}, \mathrm{IOR} / \mathrm{V} / 8 / 24$.

36 NAI, Manuscripts Microfilmed at Bharuch, Miscellaneous Documents, Sr. No. 45, Nos. 1-13.

37 Ibid.
38 Many assume that only elites had access to written law. Records from Bharuch suggest that other-agricultural and artisanal-groups also benefitted from legal writing. References to community membership (qaum) within the documents and registers support this claim.

39 East India Company, Rules, Orders, and Directions; Hull, Government of Paper, 910; Master, Diaries; Ogborn, Indian Ink, 67-103; Raman, Document Raj, 23-52; Saumarez Smith, Rule by Records.

40 I depart from Raman in "Duplicity of Paper" to suggest that Company officials employed categorical understandings of written documentation when assessing claims to accuracy and veracity.

41 Burns, "Notaries, Truth, and Consequences,"; Burns, Into the Archive; Hardwick, The Practice of Patriarchy; and Nussdorfer, Brokers of Public Trust. For a description of similar collections, see Grewal, In the By-Lanes of History; and Shakeb, A Descriptive Catalogue of the Batala Collection.

42 In his petitions, Nūr-ud-dīn refers to the practice of maintaining registers for the purposes of validating documents against possible forgeries, but there is no evidence from this or other collections that this practice existed, aside from the use of the term "naql" (copy) in the registers.

43 NAI, Manuscripts Microfilmed at Bharuch, Sr. Nos. 41 and 42.

44 For law cases see Gungeshwur Deoram (Appellant) vs. Purmanund Nundram (Respondent), Case No. 2; and Raeechund Poorshotum (Appellant) vs. Moolla Muhmood Hashum (Respondent), Case No. 11 in Borradaile, Reports, 6-7; 48-52. For dictionary definitions, see Eliot and Beams, Memoirs on the History, 157; Forbes, A Dictionary, 378; Balfour, Cyclopedia of India, Vol. 1, 1078; and Gilchrist, Hindoostanee Philology, 520 (under "quittance"). For use among nonMuslim groups, see Enthoven, The Tribes and Castes of Bombay, 330-4. 
45 It was not until the mid-nineteenth century that divorce became permissible (without requiring an Act of Parliament) in Britain under the Matrimonial Causes Act of 1857. Marriage as a religious, rather than a civil, agreement likely shaped Company understandings. Reducing access to the fārigh $\underline{k} \underline{k}$ hatți was one way to reform Muslim marriagemorally and legally. On the history of "civil" marriage in Britain and British India, see Chatterjee, "English Law, Brahmo Marriage"; and Olive Anderson, "The Incidence of Civil Marriage in Victorian England and Wales."

46 BL, OMS/Add. 26140, f. 49b.

47 See MSA, JDP, Vol. 20 of 1839. On another documentary form, see Chatterjee, "Mahzar-namas in the Mughal and British Empires."

48 NAI, Manuscripts Microfilmed at Bharuch, Sr. No. 41, No. 2.

49 Carroll, "Talaq-i-Tafwid."
50 NAI, Manuscripts Microfilmed at Bharuch, Sr. No. 41, No. 2.

51 Ibid.

52 Ibid.

53 The 1772 Plan for the Administration of Justice, otherwise known as the Warren Hastings Plan, placed "Inheritance, Marriage, Caste, and all other religious Usages or Institutions" into the category of personal law. See Forrest, Selections from the State Papers, 295-6; Cohn, Colonialism and Its Forms of Knowledge, 26; and Sturman, Government of Social Life, 6-8.

54 This argument contradicts Maine's theories in Ancient Law, passim and Cohn's observations about Benares in "From Indian Status to British Contract," 616-19.

55 Negotiations over legal categories persisted into the twentieth century. See Kozlowski, Muslim Endowments and Society; and Beverley, "Property, Authority, and Personal Law." 